\title{
Implementation of Carving Ornaments Regulation to Reinforce Jepara as Indonesian Carving City
}

\author{
Alamsyah $^{1}$, Arido Laksono ${ }^{2}$ \\ \{alam mahir@yahoo.com ${ }^{1}$, arido@live.undip.ac.id $\left.{ }^{2}\right\}$ \\ ${ }^{1}$ Department of History, Diponegoro University, Semarang 50275, Indonesia \\ ${ }^{2}$ Department of Linguistics, Diponegoro University, Semarang 50275, Indonesia
}

\begin{abstract}
The existence of Jepara carving art has been proven historically. At the time of Queen Kalinyamat in 16th century, carving art existed in Mantingan mosque, Jepara. At the beginning of the 20th century, Kartini pioneered the development of carving craft by giving training to the carving workers. In the new order (Orde Baru) period, there was a room in the presidential palace filled with Jepara carving art collection. In the reforming order period, carving craft was booming, and its quantity significantly increased. At this time, even though the carving craft was growing, yet its condition was considered fluctuating with ups and downs. The Regent Regulation No. 10 the Year 2014 about "The Provision of Carving Ornaments in Building and Other Buildings Owned by Local Government" is an effort to increase society's sense of love for the carving art. Culturally, carving art has become a source of economic life for workers, artisans, carving entrepreneurs, and Jepara society. Structurally, this regulation will produce more carving ornament products in the Jepara government buildings indicating the place as a carving city. The regulation has not been fully implemented by the government agencies in the Local Government Organizations, subdistrict offices, village, and urban village offices, schools, and other agencies.
\end{abstract}

Keywords: Protection, Regulation, Motif, Carving, Reinforce, Jepara

\section{Introduction}

The Regent Regulation No. 10 the Year 2014 about "The Provision of Carving Ornaments in Building and Other Buildings Owned by Local Government" as an effort to increase the image of carving art has made Jepara Regency as the center of the world carving. The presence of the regulation is as an effort to confirm Jepara identity as a carving city. This regulation is to give carving ornaments on the office buildings owned by local government and official residence, office buildings of social organizations, religious organizations, political organizations, community housing and places of worship [1].

The Regulation of carving ornamentation is as a structural effort of local government to make the carving craft stronger in order to become the local identity. Talking about Indonesian carving craft is related to Jepara carving craft. This carving craft influences social dynamics and economic growth of Jepara [2][3][4][5]. This carving ornament product is often implemented in the government buildings although it is distributed in most of the buildings in Organization of Regional Devices and the subordinate institutions (interview with Hadi Priyanto, Pratikno, Ratib Zaini, and Nur Sinwan, May 2017).

\section{Methodology}

This research applies the historical method consisting of heuristic, critic, interpretation, and historiography [6][7][8][9]. The heuristics are based on primary sources and secondary sources [9]. Primary sources are obtained from the local regulation archives, Jepara Regent 
Regulations, photographs of observations in the field, and interviews with regulators and implementers of carving ornaments in the buildings and offices. Interviews are conducted on individuals who are involved in the regulatory process and the ornament carving implementation. Here, some respondents were questioned and observed based on their expertise, explicitly concerning furniture business. Secondary sources are obtained from relevant works in the form of books, journal, and local magazines. These secondary sources are obtained from libraries, private collections, and also browsing on the internet. After finding the available sources, it is criticized and interpreted. The results of the analysis are then linked and reconstructed into an article on the implementation of carving ornaments in some buildings in Jepara.

\section{Findings}

\subsection{Carving craft as the local identity}

Identity is something inherent which reflects the local identity within the local scope. A person is determined by the identity he or she possesses. It is embedded in a person's outfit, dialect, behavior, or even thoughts. Having a specific identity helps a person to determine his or her roots. It then defines the ability to accept others from different ethnic, race, and culture. This ability is essential, particularly in the global era in which border is limitless.

Further, identity also has economic values since others living far away from us are also excited to learn and experience other culture. The curiosity of knowing people in different parts of the world can only be fulfilled by surfing on the internet unless they have enough money to start a journey. Thus, the threat of piracies is inevitable. A person can easily copy or use specific patterns without permission from the owner and then use the motifs as a brand or a product. This undoubtedly inflicts a financial loss for the artist or the owner of the motifs.

The research finds that the awareness toward the importance of having a patent is still low among the carving artists in Jepara city. They seem not to understand that the motifs derived from their local culture and values are valuable. The carving style and motifs are the true identity of Jepara. This has enormous economic potential both for the industry and the area itself. Such an identity is considered as a sale value that brings uniqueness and distinguishes a person to others.

Identity as the reflection of local identity becomes a requirement which is manifested in the form of crafts, including carving and batik crafts [10]. Carving craft as a product or a result of physical culture is a central element in the identity of a region either in the form of physical culture (tangible) and cultural values (intangible) of the past [11]. Carving craft with various motifs has become the identity of Jepara. The motifs are the representation of local values and culture that long have been inherited for generations. They become the local identity of Jepara embedded in the form of carving craft. This identity is sustained by the history of carving craft in the 16th century [12]. Until recently, Jepara is identical with the name of carving city whose products are well known in Indonesia as well as abroad. Almost all big cities in Indonesia become the market share of Jepara carving products. In the global context, in 2014, there are about 106 countries which become the export destinations for Jepara carving crafts [13][14][15]. Carving craft products which are considered as the breath of life of Jepara city have been recognized "worldwide." People in Jepara have experienced the golden era of furniture industries when many people utilize their homes for furniture workshops and warehouses. Furniture industries have given living to the people. In Jepara, the development of carving craft comes from local culture and identity. The process of creativity to carve derives from legends, myths and stories about the greatness of Jepara's past, the story 
of the Jepara carving artist, and the ability of the Jepara community in trading4. Those legends and myths have been told from generations in order to remind the people of their distinctive characteristics. Stories of the high power found on big trees, stones, caves, mountains, and ocean were part of the sub-conscious mind of the Jepara people determining their creative process of carving motifs and symbols. Epic stories of respected figures fighting for independence also inspire Jepara people while creating their arts. Thus, all the distinctive characteristics of Jepara motifs need to be protected and preserved. The characteristic itself determines the value of the product.

\subsection{Regulation and Implementation of Carving Ornaments}

The Regent Regulation No. 10 the Year 2014 about "The Provision of Carving Ornaments in Building and Other Buildings Owned by Local Government" is as an effort to increase the image of carving art and to make Jepara Regency as the center of the world carving industry. Before the presence of the regulation, in 2010, it was estimated that there were 99 piracies of Jepara carving ornament motifs done by several parties abroad. The piracies had caused enormous losses for the entrepreneurs, especially for the artists themselves. These pirated carving products were claimed as a result of their creativity. As a result, carving furniture artisans can no longer export their products to the country because the carving motifs used are the same as the products produced by craftsmen in their country [1][13][15]. The incident should be a good lesson for Jepara people to be aware of the importance of patent and local values preservation.

The presence of regulation is, therefore considered as an effort to reinforce Jepara identity as a carving city. This regulation is one of the policies to cultivate carving ornaments exposing Jepara characteristic which are applied in every building in Jepara. The ornaments are in the form of drawings or chisels made in a particular motif and are mounted on a building. The carving is the result of wood carving, which has a particular motif.

The purpose of this regulation is to preserve the carving culture for the beauty of the region based on the local culture as the regional identity. The scope of applying carving ornaments is mostly found on the buildings and offices. The carving ornaments are placed on the office building owned by the local government and the official residence — on the head of the building, body of the building, and bottom of the building. The implementation of the carving ornaments is also applied on the border gate of the region, the district and the village area, the gate of every office gate, and the bridge. In order to preserve the carving art, the society can participate by providing carving ornaments on the entitled buildings such as the office of social organizations, religious organizations, political organizations, community housing and places of worship [1]. By implementing this policy, the local government gradually change the people's mind to start realizing the importance of such identity to support economic sector. It is substantial for people to understand that culture holds a vital role in developing sectors of life. Applying carving ornaments in buildings and other landmarks of Jepara city arouses the awareness of people's mind to love the distintictive characteristics of their city.

Consequently, it will be deeply rooted in people's mind about the significance of having such an identity. It may not change the perspectives of all people living in Jepara, yet it will give a domino effect since people see carving ornaments all over the city. Thus, the initial goal of adjusting people's mind and behavior can be achieved.

The regulation of carving craft implementation is also issued by the legislature, although it is not explicitly aimed at carving. It can be considered as the concrete step to foster the spirit 
of reviving local wisdom. Further, it is expected that people all over the world will notice that a specific type of carving motifs is originated from Jepara. The regulation is a Regional Regulation on "Protection, Empowerment, and Development of Furniture Industry." The definition of furniture in this regulation is home furnishings which include all items such as chairs, tables, cupboards, and other supplies. The protection of the furniture industry includes the construction of facilities and infrastructure which are supporting the furniture industry, business certainty, the price of furniture products, and the prevention of unfair business competition, the provision of legal aid, and the furniture industry insurance. The relevance of this regulation with the carving craft is that every product of Jepara furniture industry tends to apply ornamental carving motifs in each product. Thus, the regulation helps reinforce the existence of Jepara carving.

In the same year, the central government issued Geographical Indication Protection on Jepara Carving Furniture with some considerations. First, the reputation of Jepara carving furniture products has been recognized in the global market. Second, the craftsmanship and unique tradition of artisans who possessed innate talents led to a furniture product which has its distinctness, and it indeed distinguishes the products from other regions. Third, Jepara carving furniture also has long history, in which the expertise, talent, and skill of Jepara craftsman are not only acquired through the process of learning but also inherited from a carving tradition of the elders, Jepara society's ancestor. The commerce of the furniture industry in Jepara has been formed and arranged in such away. Fourth, there are centers, clusters, and regions with quality product specifications which are maintained due to the response of market demands [16].

Before the issuance of various regulations, the implementation of Jepara carving on the part of buildings has been applied by some of the Regional Government Organization of Jepara Regency. Some of these buildings include the Regent's Office, the Regent's Hall, the Legislative Office, the District Office of Tahunan village, the entrance gate of Jepara City, the entrance gate of Petekean TahunanVillage, the entrance gate of Semat Tahunan Village, the Sukodono Hall in TahunanVillage, the entrance gate of SMP N 1 Welahan, etc.

Some buildings which have implemented Jepara carving motifs after the presence of Regent Regulation Year 2014 include the Tahunan Village Hall, Education and Culture Office, the entrance gate of museum, and some other government buildings.

Based on the data collected in the field, it shows that there are many buildings from the village level to the Organization of District level, which has not implemented carving craft ornaments in their buildings. Nevertheless, there are several obstacles regarding the implementation of carving ornaments on public buildings. First, there is no explicit sanction in regent regulation to a local government building which has not applied carving ornaments. The sanction here is essential to give a deterrent effect on the offender. Second, there is no technical guidance of budget proposal for the provision of carving ornaments so that it merely depends on the good intentions of the leader of the institution. When there is no empathy towards the preservation of carving, then the provision of carving ornaments is challenging to be materialized.

\section{Conclusion}

The implementation of the carving craft ornaments in buildings, gates, and bridges in the local government agencies has been supported by the regulations, which are Regent Regulation, Local Regulation, and Geographical indication of Jepara carving furniture. The key of the various regulations is the willingness to preserve Jepara carving ornaments and to 
reinforce Jepara as the national and global carving industry. The willingness of applying original ornaments of Jepara's local values should continually be socialized to every element of society. All elements in society must work together to actualize this effort. However, there is still a lack of awareness from the agencies to implement the regulation. The efforts to preserve carving craft as the Jepara identity must be maintained regardless of the little interest of citizens to pursue this softskill.

The structural effort through regulation is a long-term positive effort to preserve carving craft in Jepara. The role of the policymakers to bring this issue into the issuance of specific regulation about carving ornaments will be a firm and robust step for the existence of the carving industry in Jepara. Hence, it is expected that the people in Jepara are aware of the importance of having a specific regulation to protect their work of art.

\section{References}

[1] P. Indonesia, Peraturan Bupati Jepara Nomor I0 Tahun 2014 "Tentang Pemberian Ornamen Ukiran Pada Gedung Dan Bangunan Lain Milik Pemerintah Daerah.” 2014.

[2] Alamsyah, "The ups and downs of wooden furniture industry at the North Coast of Java Pre and in post reformation: a case study on Jepara wooden furniture center. P," in roceeding of the 1st International Conference on Southeast Asia Maritime World, 1, 2016.

[3] Alamsyah, "Kreativitas Ekonomi Masyarakat Lokal di karesidenan Jepara, 18301900,” J. Paramita Unnes Semarang, vol. 23, no. 1, p. 41, 2013.

[4] J. and B. M. S. Schiller, "Market, culture, and state in the emergence of and Indonesian export furniture industry," J. Asian Bisnis Issues, vol. 13, no. 1, p. 3, 1997.

[5] T. Lindblad, "Economic aspects of the Dutch expansion in Indonesia, 1870-1914," J. Mod. Asian Stud., vol. 23, no. 1, p. 8, 1989.

[6] G. J. Garraghan, A guide to historical method. New York: Fordham University Press., 1947.

[7] L. Gottschalk, Mengerti sejarah. Trans. Nugroho Notosusanto. Jakarta: Penerbit Universitas Indonesia, 1975.

[8] H. Sjamsudin, Metodologi sejarah. Yogyakarta: Ombak, 2007.

[9] N. Herlina, Metode Sejarah. Bandung: Satya Historika, 2008.

[10] I. and E. K. Iskandar, "Batik sebagai identitas kultural bangsa Indonesia di era globalisasi," J. Gema, vol. 30, no. 52, p. 2456, 2016.

[11] G. and C. M. Davison, A heritage handbook. New Jersey: Allen \& Unwin., 1991.

[12] S. . Gustami, Seni kerajinan mebel ukir Jepara; kajian estetik melalui pendekatan multi disipli. Yogyakarta: Kanisius, 2000.

[13] G. Magazine, “Gelora Magazine,” 171, March, p. 11, 2015.

[14] Gelora Magazine, "Gelora Magazine," 173, May, p. 49, 2015.

[15] Gelora Magazine, "Gelora Magazine," 120, March, p. 7, 2011.

[16] Tim JIP-MUJ, “Jepara Indikasi Geografis Produk-Mebel Ukir Jepara (JIP-MUJ), Jepara: Indikasi Geografis Mebel Ukir Jepara, Jepara),” 2014.

List of Respondents

[1] Pratikno, Address: RT 02, RW 03, Potroyudan Sub-district of Jepara, Deputy Chairman of Assembly at Provincial Level, Educational background: Senior High School, date of interview 6 May 2017

[2] Hadi Priyanto, Address: Desa Bondo RT01/RW07 Sub-district of Bangsri, Jepara, 
Chairman of Weaving and Carving Conservation Jepara since 2011 and Head of Public Relation, Regency of Jepara, Educational background: Master degree, date of interview: 7 May 2017.

[3] Nur Sinwan, Address: Pecangaan kulon RT 05 RW 05, sub-district of Pecangaan, Division Head of Law, Regional Government of Jepara, Educational background: Master degree, date of interview: 8 May 2017.

[4] Ratib Zaini, Address: Pelem Kerep RT 04 RW 03, Mayong Jepara, Head of Sub-district of Tahunan, educational background: Master degree, date of interview: 9 May 2017 